\title{
Narrating as an Answer to Sociocultural Challenges
}

The narratives told by the network actors and bloggers from different parts of the world who participated in the study revolve around questions about their own lives and social relations but also frequently around issues concerning developments in society and the media as well as the relationships between all of these areas. Klaus Hurrelmann and Erik Albrecht attest that adolescents and young adults, the age group the network actors and bloggers belong to, have an awakened sensitivity when interacting with each other and their environment $(2014$, p. 15). According to the authors, they are more actively engaged with what is happening to and around them than any other age group because for them, it is a question of finding their own spot in society $(2014$, p. 15).

Born for the most part between 1985 and 2000, the network actors and bloggers in this study mostly belong to Generation $\mathrm{Y}$, as the millennials are also known. A generation is made up of a demographic cohort confronted with the same social events and challenges. The pivotal experiences common to Generation Y are associated with the sociocultural upheavals which are taking place globally at present on both a macro and a micro level. The synchronization of social structures and individual needs is being put to the test by these upheavals and the first cracks are starting to show (Keupp, 2015, p. 7). When people are no longer confident about spatio-temporal references in relation to which they live their everyday lives and map out their identities, or when they experience them as being restrictive, it is necessary to start mulling them over $(2015$, p. 7$)$.

(C) The Author(s) 2020

C. Schachtner, The Narrative Subject, https://doi.org/10.1007/978-3-030-51189-0_6 
That is yet another reason for adolescents and young adults to grapple with social changes by telling stories. The network actors and bloggers do this both implicitly and explicitly in their narratives, which are about the search for new life trajectories and networks of relationships, about shifting boundaries and defining new ones as well as about setting out and breaking away.

The relationship between subjects, their narrative practices, and social transformation lies at the heart of this chapter. The main question relates to the extent to which the narrations presented here reflect this transformation, or the extent to which they provide answers to sociocultural challenges. This concern is based on the assumption that individual and social goings-on are connected with each other (Keupp, 2015, p. 31). "What it means to be a person is social and cultural 'all the way down'" (2003, p. 220) is how Chris Barker formulates the social and cultural construction of the subject. This should not be thought of as deterministic, however; interdependencies are much more likely. Subjects, society, and culture develop in interaction with each other (Honneth, 1990/1995, p. 58), with subjects entering into these interactions with their current questions and influenced by their autobiographical experiences. In phases of social upheaval, narratives gain special significance as mediators between the macro and micro levels.

There is a long list of phenomena of transformation specified in literature on the topic in social and cultural studies. Without presuming to cover the entire spectrum of phenomena of upheaval, I have selected five of them for my discussion of potential links between the narrations of network actors and bloggers and sociocultural upheaval, namely detraditionalization, pluralization, the blurring of borders, individualization, and global flows. In a first step, I will describe these phenomena of social transformation, before relating them to the stories with the intention of identifying possible overlaps.

\subsection{DETRADITIONALIZATION}

In the Western world, the process of detraditionalization started in the modern period. According to Zygmunt Bauman, the most powerful motivation was to dismantle the old order to "liberat [e] business enterprise from the shackles of the family-household duties" (2000, p. 4). He suggests that "'releasing the brakes': of deregulation, liberalization, 'flexibilization', increased fluidity, unbridling the financial, real estate and labour 
markets" (2000, p. 5). Social and cultural life was also affected by the breaking up of traditional structures; traditional values, norms, and life trajectories lost their validity or proved to be ineffectual. Normative commitments and social bonds were "thrown into the melting pot" (2000, p. 6); Bauman speaks of an "unstructured, fluid state of the immediate setting of life-politics" $(2000$, p. 8$)$ which has radically changed the human condition, proposing that modern subjects have to do without the traditional patterns of orientation which would have framed their life plans (2000, p. 7). Against the background of this historical development, detraditionalization is associated with loss, disassembly, and decay. From this perspective, detraditionalization appears to be something which befalls the subject.

Detraditionalization can also be deliberately pursued by subjects, however, as tradition clashes with the visions of the future held by the next generation. This is most clearly illustrated in the narrations about setting out and breaking away told by the Arab network actors and bloggers. The links between politics and religion, which are traditionally extremely tight, the lack of freedom of opinion and speech, and the ban on debate, which is culturally determined: All of these are seen as shackles which need to be cast off. Here, detraditionalization is not a side effect of macrostructural developments but a process triggered off by everyday actors. In both cases, it is true to say, however, that life forms lose out on the "structural fabric, traditions, and predictable measures against which subjects could orient their life plans, biographies, and identities" (Keupp, 2015, p. 7). ${ }^{1}$

In relation to an order which has been lost or abandoned, for Generation $\mathrm{Y}$, whether in Western or Arab countries, the Other is expressed in terms of vagueness, unpredictability, and precarity. This can lead to fear, which Heinz Bude describes as a typical feeling in Western societies in his book Society of Fear (2014/2018). Detraditionalization becomes a source of fear, especially when it is experienced as a loss of security. As Bude points out, "anxiety springs from the knowledge that everything is open but nothing is meaningless" $(2014 / 2018$, p. 8). Everything that we do counts, everything that we do could trip us up; with everything that we do, our entire lives seem to be up for renegotiation $(2014 / 2018$, p. 8$)$. In contexts where there is a desire to dismiss traditional structures, it is the risks arising out of resistance to die-hard opponents of change which tend to give rise to anxiety. What is left in any case is a feeling of insecurity in

${ }^{1}$ All quotations from German publications were translated into English for this book. 
view of a different future which may be desired but which is also totally open.

According to Hurrelmann and Albrecht, the unpredictable nature of their life trajectories is the most important hallmark of Generation Y and, at the same time, their greatest challenge $(2014$, p. 35). Generation Y has to learn how to deal with various forms of unpredictability, for example, by

- Adapting to the requirements of a changed reality

- Reinventing themselves time and again

- Negotiating consensus on a non-stop, never ending basis

The network actors and bloggers react to the erosion of traditional structures and patterns with a high degree of reflection, which runs through all of the narrations, regardless of the nationality of the narrator. Values are at issue, love or loyalty, for example, and how they have to be interpreted nowadays, or the appropriacy of one's own behaviour in encounters with Others or when interacting with technology, but also the behaviour of Others, or traditional structural orders and political rights, a problem which was discussed by the Arab narrators above all.

Life trajectories which have become unpredictable and the requirement to reinvent the self are matched by the seeking I, which appears on the scene in the self-staging narrations, which is presented in a blog in the hopes of getting feedback on the blogger's strengths and weaknesses, or which impresses readers with a carefully designed virtual I which also embodies an ideal image as the goal and incentive for the narrator's own development. The seeking I craves approval, as confirmation for being on the right track. Time and again, we heard that approval and praise are like "balm for the soul."

As is to be expected, the theme of searching is also found in the transformation narrations of the pubescent network actors and bloggers, who are confronted not only with sociocultural transformation but also with a phase of biographical upheaval. The theme comes up quite strikingly in the transformation narration of the 12-year-old who asked the question about identifying the right thing, which is actually a question about the "right life," putting it at the heart of her story (see Sect. 4.5.2). She exploits the possibilities of the virtual world to process this question. In the end, she felt, it is the physical presence of a body which is the sole guarantee for what is "right" because in her eyes, it cannot lie. For her, social encounters have to take place face to face for them to be right and 
proper. The popularity of role-playing games, both online and offline, which the children and adolescents talked about, also points to the search for patterns of behaviour and meaningful relationships. They offer them the opportunity to find out what comes across best or finds acceptance, without having to commit to one thing or the other. The seeking I associated with the narrating children and adolescents is forced to reconstruct its values when faced with the erosion of society. This does not preclude a critical scrutiny of old and new values but we are not dealing with a rebellious I here.

The setting-out and breaking-away narrations of the Arab network actors and bloggers are very different as they rebel against constrictive traditional structures. Their narrations reveal their use of digital networks to break taboos, constitute alternative public spheres, and create elbowroom for expressing their opinions. The transnational opportunities for communication afforded by digital media are also used to show the world other sides of their cultures which the narrators believe are suppressed by the official media. This is indicative that traditions should not be shelved wholesale but that a distinction should be made between constrictive traditions and those which are held in high regard.

Whether it is a question of replacing traditional cultural systems because they have disappeared or have become ineffectual or because they are no longer acceptable, in all narrations about detraditionalization of one kind or another, the need to shape them anew is very pronounced. This need, in turn, expresses the hope that it will be possible to influence the future according to the individuals' wishes.

\subsection{Pluralization}

Plurality, Wolfgang Welsch is convinced, lies at the heart of modernity, all the while pointing to a sociocultural hereafter which he calls the postmodern (1988, p. 13). Because I would like to emphasize the processual nature of this phenomenon, I will not speak of plurality but of pluralization. The concept of pluralization describes the multiplication of life spaces which are accompanied by a proliferation of demands and offers alike. This process, too, is rooted in the logic of the modern and of its own economic forces which prompted the diversification of the economic sector, the division between gainful and reproductive employment, and increased mobility in connection with education, work, and relationships. Individuals who wanted to raise their level of education had to move to towns or cities to 
pursue educational programmes; those who wanted to improve their chances on the job market had to move to places where many jobs were available. This trend still has mileage today. The superiority of "nomadism" over "sedentarism" is looming (Bauman, 2000, p. 13), shaping more and more ways of life in the era of Liquid Modernity, the title of Bauman's (2000) book, while the sedentary way of life is losing its significance.

Pluralization is not a completely new trend, but it is increasingly capturing our attention as it has become more intensive as it speeds up. The media have not an insignificant role to play in this development. Books and newspapers are early examples of media taking us beyond our immediate physical vicinity into other experiential worlds. Meyrowitz describes how telephones, radios, and televisions amplified this because they were easier to consume or to use, because increasing numbers of everyday activities were connected with these media, and because they expanded the spectrum of experiential worlds significantly (1985, p. viii). Now digital media are carrying the multiplication of spaces to extremes (Schachtner, 2013, pp. 20-21). Digital spaces are opening up to all sorts of contents and can thus serve as spaces for working, learning, selling things, and flirting, as well as distributing information and enabling communication. What is more, none of these different spaces stop at national borders (2013, pp. 20-21). In contrast with print and audiovisual media, not only do digital media provide a wealth of experiences; we ourselves can also become active in digital spaces. According to William J. T. Mitchell, the internet is organized like a multitude of "parallel computation device[s]" which provide us with a world of interconnected spaces in which we can communicate, work, learn, and play in overlapping relationships (2003, pp. 13-14). The network actors and bloggers take it for granted that they can use several digital networks, information networks, and computer games, often almost simultaneously. They can do this anywhere and at any time, for digital media have become mobile thanks to the miniaturization of many devices; the plethora of spaces they offer fits in every handbag and jacket pocket. This encourages network actors to saunter not only between virtual spaces but also between virtual and physical spaces, as the visualization provided by a 22-year-old network actor from Austria illustrates (Fig. 6.1).

To start with, the 22-year-old only wanted his drawing to show that he uses different apps like Twitter, Google, and Soup.io (2017-2019) ${ }^{2}$ on his

\footnotetext{
${ }^{2}$ Soup.io (2017-2019) is an Austrian social networking und microblogging site.
} 


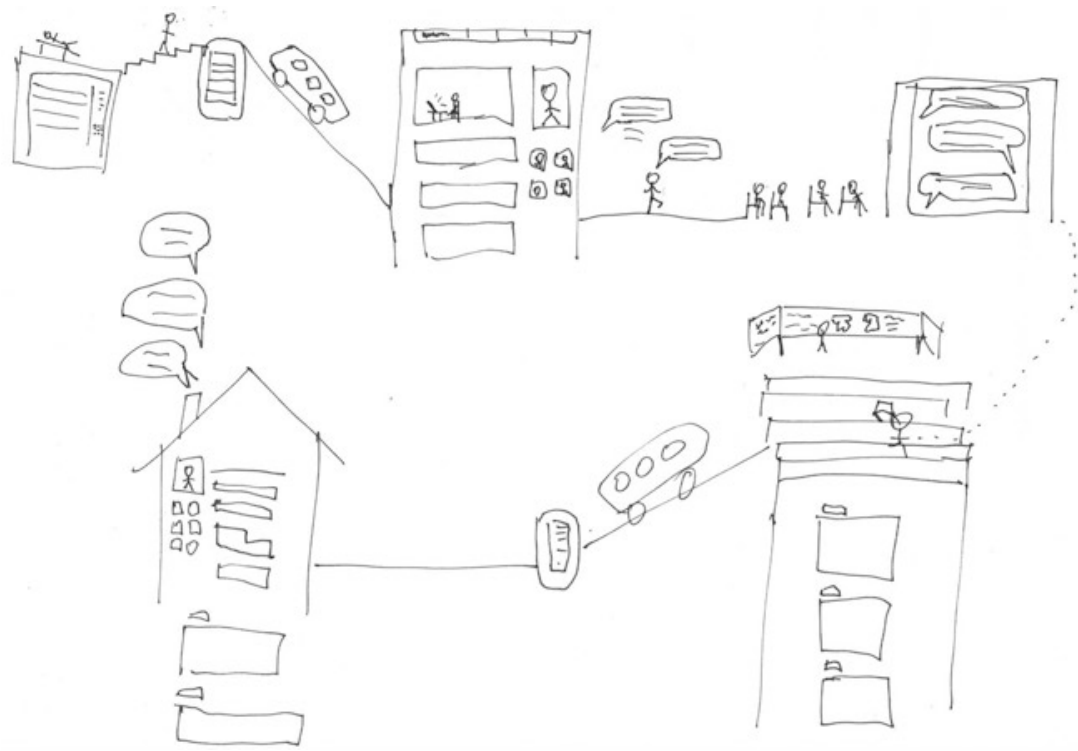

Fig. 6.1 Communicating, working, and learning in overlapping spaces (network actor, $\mathrm{m}, 22$, Austria)

mobile phone, but then it turned into a representation of his daily routine, starting with getting up, taking a bus to work, going to a class at university, and then taking the bus back home again. Speech bubbles show how he is connected with virtual spaces all day long and is also aware of being so. He moves and acts in shifting virtual spaces as well as in shifting physical spaces, as visualized in his drawing. From his perspective, his actions in virtual space happen "in passing" or "in parallel," as he put it.

Caused by the pluralization of life spaces and reinforced by the media, life becomes a "life in the plural," a developmental trend which Wolfgang Welsch (1988) already identified in the 1980s. Especially Generation Y is likely to adapt to these life trajectories as, worldwide, if the situation in Germany is anything to go by, their age group uses digital media most frequently. ${ }^{3}$ A "life in the plural" poses challenges and makes demands.

${ }^{3}$ According to Birgit von Eimeren and Beate Frees' (2011) study, at the time of the narratives in this book, $100 \%$ of 14 - to 19 -year-olds and $98 \%$ of 20 - to 29 -year-olds in Germany were using the internet (i.e., the age groups representing Generation Y). 
Faced with the juxtaposition and interlocking of digital and physical spaces, subjects come across a wide range of images, temptations, and offers, and do not necessarily know how they fit together (Schachtner, 2013 , p. 23). "You don't know how the two worlds are going to cross" is how Sherry Turkle describes it (2011, pp. 196-197). Turkle is understating her case when she speaks of only two worlds because, even when taken alone, the digital world and the physical world are intrinsically heterogeneous, without taking the overlapping spheres of virtual and real life into account, which is like a third space, or an intermediate space. The frequent and often rapid switch from one life space to another runs the risk of fragmented experiences and losing the feeling of leading a cohesive life. Pluralization is a contradictory process as it can represent a broadening of options as well as an increase in tensions and conflicts at one and the same time. Those who would like to participate successfully in a "life in the plural" need to be tolerant of ambiguity, competent in plurality, and proficient at mastering transitions (Welsch, 1991, p. 357).

The network actors and bloggers counter the risk of a "life in the plural" disintegrating into individual, isolated pieces with the help of narrative practices that target the establishment of coherence, as in the stories which illustrate interconnectedness but also in those which talk about setting out and breaking away. Digital media have a high priority for Generation Y when attempting to live a life which is coherent as they use such technology to help connect events or people from different contexts. Remember the American globetrotter who took photos of the everyday and the mundane on her travels through various countries and then posted them in an online photo gallery. That was her way of piecing all of her everyday experiences into a colourful mosaic which formed a coherent whole despite the many differences. She explained that another advantage of the online presentation was that she could use the images to bridge the gap to her family, making it possible to integrate her home space into her current environment. Making connections between distant family members and networks of friends with the help of online images, texts, and sound in the here and now is a common strategy for millennials. Kraus describes the struggle for coherence as being absolutely essential; foregoing this struggle would result in the dissolution of the subject $(2000$, p. 15).

However, the different spaces and experiences associated with them do not always come together harmoniously. This is particularly noticeable in some of the narratives of the Arab network actors and bloggers which explicitly point out that the narrators' online presence can differ massively 
from their offline mode. The reason they give for this is the discrepancy between their own opinions and sociocultural limits. Some of them feel that they are fragmented, as they put it; others say that they remain the same in the various contexts. This could be explained by their viewing their different behaviours as just another facet of their identities or by their maintaining a particular self-concept, regardless of the way they behave in the different contexts, which is invisible to the outside world.

Seen in the light of their narratives, the network actors and bloggers shape their strategies for dealing with plurality in different ways, depending on their personal lives; what they have in common with each other is that they have to figure out these strategies for themselves because there is no generic solution.

\subsection{The Blurring of Borders}

The pluralization of life spaces results not only in extended spaces but also in overlapping spaces, which, in turn, lead to a blurring of borders which is only amplified by the influence of the media. In contemporary society, the contexts in which the blurring of borders is becoming increasingly apparent and in which it is promoted or even initiated by online media include the blurring of geographical or national borders, between work and leisure time, ${ }^{4}$ and between the public and the private. This section explores the latter; the geographical blurring of borders is addressed in Sect. 6.5 on "Global Flows, Crossovers, and Hybridity."

Jürgen Habermas has suggested that there are dividing lines between the public and the private which he considers to be constitutive for modern democratic societies (1962/1990, pp. 27ff.). The emergence of a private sphere in which the individual could develop, safe from state interference, was celebrated as a gain in freedom and autonomy in political philosophy (Jurczyk \& Oechsle, 2008, p. 9). It is a normative concept, however, which has presumably never existed in such a pure state in reality. Even in the 1960s, when Habermas' book was first published, he observed that the "intimate sphere" had become public and, as a result of that, "the public sphere ... assumed forms of private closeness" (1962/1992, p. 158).

\footnotetext{
${ }^{4}$ The blurring of borders between work and free time was investigated in the part of the project carried out by the TU Hamburg-Harburg (see Carstensen, Ballentien, \& Winker, 2014, pp. 29ff.; see also Roth-Ebner, 2015).
} 
It is largely developments in the media which have contributed to the erosion of existing or imaginary borders. Issues from individuals' private lives are popular subjects for media productions nowadays (Jurczyk \& Oechsle, 2008, p. 8). Bringing up children, choosing a partner, everyday family life, and sexuality have become ubiquitous topics in talk shows and on reality TV. ${ }^{5}$ The digital media have massively increased the options for disseminating private details because they offer spaces which can be filled by the users themselves but to which, potentially, the entire world has access. In the narrations of the network actors and bloggers, this state of affairs is sometimes welcomed, but sometimes it is described as being frightening or threatening. Those who present themselves as stars on a virtual stage, as is the case with "the adored star" in the self-staging narration (see Sect. 4.2.1), for example, enjoy the attention paid to them by the global public; those who know that their online presence is at variance with traditional cultural order experience the public character of virtual space in a more ambivalent fashion. On the one hand, as the network actors and bloggers from the Middle East would have it, they see their online public as a welcome chance to develop an alternative political discourse which goes beyond regional borders, very much in the spirit of the Habermasian concept of the public sphere; on the other hand, they fear retaliatory measures from the political and administrative authorities. Most of the narrators were not aware of the visibility of virtual spaces right from the start; some of them spoke about their carefree use of digital media when they were children and adolescents. As already mentioned, one of the network actors talked about how she was not really aware of her public personality until she mingled with people, quite by chance, who were just looking at and commenting on her Flickr album, and was really shocked (see Sect. 4.4.2).

Most people who are active in the internet do not see themselves as being part of a public sphere. It is not even necessary for them to physically leave their private sphere: One swipe on their smartphone screen or one click on the keyboard of their laptop suffices to bring public life into the privacy of their own four walls. Programmes on television about public spheres elsewhere are complemented by videos which, since the appearance of so-called smartphone videos, are available on digital networks and blogs in incredibly large numbers. Just one tap on the screen or keyboard

\footnotetext{
${ }^{5}$ Reality TV claims to present everyday life-worlds in which exceptional circumstancesbirth, marriage, or death, for example-are represented authentically or are reconstructed.
} 
and what is meant to be out there is hauled onto one's own desk. In this way, a public sphere is created in the midst of a private sphere, or something new is created, the term for which has not yet been coined.

When existing or imagined classifications become obsolete, as in the case of the blurring of borders between the public and the private, an established order starts to unravel. The relationships change between certain actions and the consequences of these actions. We can no longer rely on "past successes as guides for future ones" (Bauman, 1991, p. 2). Subjects are challenged to find new classifications, or to develop "acts of inclusion and exclusion" (1991, p. 2). Including virtual spaces in a new classification of the public and the private poses particular problems for subjects because in these spaces they are confronted with a reality which is different from the world beyond digital media. Indeed, it is this otherness which they still have to explore.

The structural blurring of borders between the public and the private is most clearly reflected in the stories about managing boundaries. In these narratives, not only is the blurring of borders addressed; strategies are also described which should establish new classifications. These include selection and differentiation. Selection refers to content matter which is presented in public online, or not presented, as well as to individuals to whom specific content matter is addressed, or not addressed, depending on where they find themselves on the bridge they have spanned between the public and the private. Differentiation, in contrast, refers to the division of virtual space into public and private forums. The most impressive example of this can be found in the story about managing boundaries which was told by the 27-year-old Arab blogger who kept three different blogs in which she drew her boundaries between the public and the private in quite different ways (see Sect. 4.4.1).

The stories of the network actors and bloggers reveal not only awareness of the blurring of borders between the public and the private but also the need to set clear boundaries and not to let themselves drift into unclear situations. Müller-Funk gives reasons which could explain the need for boundaries when he defines their character as representing detachment or connectivity (2012, p. 81). When boundaries disappear, Müller-Funk believes, contact cannot arise (2012, p. 80), but human subjects cannot forego that. In that sense, boundaries are a constitutive feature of human existence.

In connection with the personally defined boundaries described by network actors and bloggers in their narrations, there are two interesting 
effects. Firstly, boundaries are not described as being definitive. Secondly, the defining of boundaries appears to be an individual achievement. In the narrations there is talk of border zones which can be varied. The lack of a social model for configuring the relationship between the public and the private is seen by the narrators as a chance to take this configuration into their own hands, every man/woman for himself/herself. If it is true that boundaries determine the possibilities of social togetherness, as deduced from Müller-Funk's musings, the situation cannot stay as it is. Consensual negotiation of border zones will have to replace individually defined boundaries.

\subsection{INDIVIDUALIZATION}

The individualization thesis signals the disembedding of the individual from social structures, as manifested in the dwindling importance of the "inner social structure of industrial society" (Beck, 1986/1992, p. 87; see also Beck \& Sopp, 1997, p. 10), like classes or social milieu. Once again, those collectively shared life trajectories and blueprints for identity are vanishing which appear to be inadequate or are becoming insignificant (Beck, 1986/1992, pp. 87ff). The individualization thesis is also a Western issue in this respect; seen through a sociological lens, losses and the withdrawal of certainties are accentuated in connection with tendencies towards individualization. In the stories of the Arab network actors and bloggers, individualization is also addressed but rather as a rebellious process springing from those individuals who wish to escape from the constraints of handed-down social relations and their traditions. In the Western world, individualization can also mean freeing ourselves from the confining structures of class, stratification, and family roles, which is not to say that traditional social forms always offered integration to individuals in the form that they desired (1986/1992, pp. 87ff.).

Either way, whenever social ties disappear or are cast off, subjects are left to their own devices. According to Zygmunt Bauman, for whom the dismantling of social "patterns, codes and rules" $(2000$, p. 7$)$ comes close to "Orwellian and Huxleyan-style nightmares" (2000, p. 15), the goals of "individual self-constructing labours [are] endemically and incurably underdetermined" $(2000$, p. 7$)$. In a society in which connecting links have been assigned to the waste bin, in Beck and Sopp's eyes, neither the political system nor the cultural-normative system can be expected to 
accomplish social integration; that is up to each and every one of us (1997, p. 12).

Against the background of the empirical data collected in the study "Communicative Publics in Cyberspace," I go along with the individualization thesis in as much as individualization implies structural disembedding on the one hand and a reconstitution of the individual on the other. The latter is not necessarily just an individual accomplishment, however, as illustrated by the stories of the network actors and bloggers; it can also be conceived of as a collective accomplishment, particularly with an eye towards the Arab narrators. In relation to the narrations investigated here, it is the attempts at Self-construction, whether individual or collective, which are of particular interest in the process of individualization.

According to Kraus, narrating is a fundamental mode for constructing reality, which includes Self-constructions $(2000, \mathrm{p} .4)$. That is why it is hardly surprising when we come across practices of individualization in almost all narrations, particularly in the narrations about self-staging, suppliers and sellers, transformation, and setting out and breaking away.

In the self-staging narrations, there are two kinds of attempts at individualization: an egocentric form and a You-oriented one. The narration of "the adored star" represents the egocentric form, with the 29-year-old narrator characterizing himself as a super cool guy who masters his life by his own means. It is his intention to present himself online, as he related it, "without the lumps and bumps," as "a tough cookie" who can ward off any disaster and whose status symbols lie at his feet, just like the Others who admire him so much, as shown in his visualization (see Fig. 4.2 in Sect. 4.2.1). It seems as though he acquires his strength and superiority from within; the Others are in demand as spectators. But he cannot actually do without them, which contradicts his staged independence.

In the You-oriented kind of individualization, the protagonists living in Europe also put themselves at the heart of their life planning but they do not see themselves as independent actors. They recalled goals which they had chosen themselves and self-representations which they deliberately posted online for an audience with the aim of eliciting their comments. It clearly emerges from their narrations that the comments serve as points of orientation; the narrators hope for praise and affirmation but do not close their minds to criticism either, if they believe it can help them advance.

Another answer to the current surge of individualization which calls for every single person to shape their own lives is the use of virtual space as a location for practising skills which promise the individual a successful life. 
Answers of this kind can be found in the narrations about suppliers and sellers as well as in the transformation narrations. Examples include the stories told by the 14-, 22-, and 24-year-old bloggers from Europe in which they described how they framed themselves as an online expert for endorsing technical and media products, a project manager, or a designer. In his transformation narration, the 11-year-old described how he uses the internet as a place not only for learning about famous footballers' tricks but also for practising them himself. His goal is to become a world-famous footballer whose accomplishments are highly remunerated.

Hurrelmann and Albrecht describe Generation $\mathrm{Y}$ as a generation in which everything revolves around their jobs and careers so as to ensure that their futures are as promising as possible (2014, p. 30). In the attempts at individualization detected in this study, it is also about the desire for a successful future. In the self-staging narrations, this wish remains rather vague; in the stories which are about practising skills and improving expertise, it becomes more concrete. Career goals do not stand in isolation, however, but are connected with the desire to have a fully developed personality. The stories reveal a generation which has goals to pursue, in contrast to Bauman's (2000) assumption that millennials rather lack an aim in life. It is just that the goals are not determined from the outside but are set by the individuals themselves. The narrative answers which relate to the process of individualization underline that the actors may act as though they are entrepreneurs in charge of themselves and their lives but their actions always relate to Others as well, even when they imagine themselves to be completely independent.

Social orientation comes across strongly in the narrations of the Western network actors but it appears even more strongly in those of the Arab narrators. Their stories also announce a desire for new, forward-looking selfrepresentations, for self-determination, and for self-realization. But the desire for personal development is closely linked with the desire for sociocultural transformation. According to the narrations, the desire leads to actions which aspire to reconstruct individuals and society alike as a collective undertaking. The digital networks, which the narrators perceive as being protected spaces, should help them in the endeavour to find allies and comrades-in-arms. As mentioned in Sect. 4.6.2, in contrast to the Western narrators, they do not find themselves in a situation in which sociocultural traditions have become meaningless; on the contrary, they find themselves surrounded by guardians of tradition who react to deviations from the norm with threatening gestures. Unlike the Western 
narrators, the Arab narrators clearly state that individualization, in the sense of a self-determined way of life, is only conceivable once the sociocultural context has changed. Their knowledge of the power of the diehard opponents of change initially triggers acts of individualization as collective acts, the results of which then have to be translated into individual acts. Opportunities for individuality arise from the fact that "each human being is different from all those who have lived, who live, and who will live" (2000, p. 89), as Adriana Cavarero puts it.

In order to take it up again: Whether the acts which aim at a selfdetermined repositioning of the individual in society are planned as individual or collective acts, they always arise in conjunction with Others. The social nature of our actions has to do with the fact that we are born into a social world; in other words "we are constituted as individuals in a social process using socially shared materials" (Barker, 2003, p. 222). Barker continues, saying that "[n]obody is free in the sense of undetermined" $(2003$, p. 237). This does not speak against self-determination, for different individuals will reach for different materials in order to create their life models out of them (Welsch, 2001, p. 280).

Current sociocultural upheaval increasingly calls on network actors and bloggers to be designers of their own futures. As such, they generate themselves when working on their self-representations online, when they experiment as role players, when they set themselves "sparkly" goals, when they are willing to take risks in pursuit of their dreams, and when they overcome linguistic and political barriers in order to engage in conversation with Others from all over the world.

\subsection{Global Flows, Crossovers, and Hybridity}

Global flows in the form of movements of capital, commodities, migrants, communication, and information rank amongst the most distinctive characteristics of the social and cultural upheavals which we are experiencing at present all over the world, yet such flows are not a completely new phenomenon by far. The Silk Road which emerged in the pre-Christian era and along which merchants, goods, and culture travelled from east to west and back is one such example, as are the migrations in central and southern Europe in the fourth and sixth centuries. Economic crises have repeatedly led to waves of emigration; for example, since the beginning of the seventeenth century, there have been several periods in which Germans left their home country for the USA. What is new is that modern-day 
transterritorial flows now exist concurrently, are picking up speed, have intensified, are much more interdependent, and are visible all over the world (Schachtner, 2009, p. 5). Just about everything which can move these days is moving, in John Urry's eyes, and doing so at stunning speeds in all possible directions: "People, machines, images, information, power, money, ideas and dangers are all, we might say, 'on the move', travelling at bewildering speed in unexpected directions from place to place, from time to time" $(2003$, p. 2$)$. The multidirectionality of global flows triggers a reciprocal crossover of these flows.

In the context of the questions being dealt with here relating to phenomena of sociocultural change, the cultural dimension of global flows is particularly interesting. Not only things but also ideas are borrowed from other countries and combined in completely new ways. One example for this is the Italian fashion label Etro, which adapts themes, patterns, and colours from another part of the world every season, combing them with Italian flair. Another example is the integration of Far Eastern traditions in treatment plans based on Western medicine. The communication flows making use of digital media increasingly feed on more than one language at a time. Nederveen proposes the concept of "global multiculture" $(2010$, p. 81$)$ to give this multifaceted crossover a name, using this term to capture the global interdependence and nomadic nature of this process. Wolfgang Welsch rejects the concept of multiculturality because, for him, it is tied too strongly to the idea of single, homogeneous cultures (2001, p. 260). He pleads instead for the notion of transculturality, which makes it quite clear to him that no culture is an island; instead cultures permeate each other (Welsch, 2012, p. 26). The new model for society should not be that of a closed sphere but of a network $(2012$, p. 28$)$. Transculturality describes a normative concept, although Welsch claims that it increasingly reflects reality and is not just wishful thinking $(2012$, p. 36). What is common to both Nederveen's and Welsch's concepts is that the postcolonial perspective is missing which was formulated by postcolonial studies in the 1990s and says that we live in a world which was basically built on the relations between the colonizers and the colonized which still have an effect on our lives today (Dirlik, 2010, p. 33). ${ }^{6}$ Arif Dirlik points out that this

\footnotetext{
${ }^{6}$ In the completely new and revised second edition of his book Transcultural Communication, media expert Andreas Hepp attempts to integrate the postcolonial perspective with reference to Homi K. Bhabha (1994) in the concept of transculturation or transculturalization which he adapted for media studies (2015, pp. 18ff.).
} 
influence is visible in the inequalities between industrialized economies and the countries of the so-called Third World in the areas of economic and infrastructure development as well as in education and social stability. One global effect of this inequality which is all too visible at present is the migration flows from countries which had no opportunities for economic and political development under colonial rule and which are, therefore, still unable to safeguard the livelihoods of their inhabitants and/or do not have adequate political and administrative structures in place which would be in a position to respect human rights. Migration is only one way in which those on the margins of society can speak out. The one-way road between the mainstream society and its margins has been broken up in principle.

Developments in the media are a key factor when it comes to global crossover. At this point I would like to return to the discussion started under the heading of "Structural Characteristics of Digital Media" in Sect. 3.2. Conveying information, ideas, values, and lifestyles, the worldwide flows of images and texts are infiltrating what were once thought of as nationally defined cultural maps (Hess \& Lenz, 2001, p. 19). Global trade, the coordination of international politics, and the organization of global social movements but also projects in the music and film industries as well as in the art world would be inconceivable without transnational digital media which connect places and regions with each other like a giant underground web.

Global interplay as a result of criss-crossing global flows accelerates hybridization, which Welsch construes as influences from all other cultures taking root domestically in any one culture on the level of its population, goods, and information (Welsch, 2012, p. 28). Bhabha links hybridization with the concept of the Third Space, which allows him to sound out the qualitative potentials of hybridization (Babka \& Posselt, 2012, p. 9). For Bhabha, hybridization is a movement $(2012$, p. 66) which constitutes the Third Space but which does not represent a limited geographical area (2012, p. 68). The Third Space is a "connective tissue" (Bhabha, 1994, p. 4) which resembles a stairwell in which the binary order disappears, or as Bhabha phrases it, "the hither and thither of the stairwell, the temporal movement and passage that it allows, prevents identities at either end of it from settling into primordial polarities" (1994, p. 4). He continues: "This interstitial passage between fixed identifications opens up the possibility of a cultural hybridity that entertains difference without an assumed or imposed hierarchy" (1994, p. 4). 
In contrast to Welsch, Bhabha does not want hybridization to be interpreted as a simple blend "but as a strategic and selective adoption of meanings, creating space for people to act whose freedom and equality are at risk" (Babka \& Posselt, 2012, p. 13). Bhabha constitutes the Third Space as a space for criticism and subversion, without wanting to maintain that it operates in a power vacuum. Even in the position of an underdog, it is possible to upend imposed cultural authorities, taking on some aspects and rejecting others (Babka \& Posselt, 2012, p. 13). Bhabha's Third Space reminds us of Foucault's heterotopias (1967/1997). The two concepts resemble one another with regard to the critical impulses ascribed to both of them as well as their characterization as an in-between space. Admittedly, Bhabha emphasizes the encounter of cultural differences within the Third Space much more strongly while Foucault insists on the Other of heterotopias, or on the difference in spaces in relation to what is taken to be normal, for example by psychiatry. In addition, Bhabha sounds out the Third Space for its postcolonial influences, which Foucault did not keep in mind.

In a world permeated by cultural flows and hybridization, the challenge we face is to take note of and acknowledge the existence of cultural differences. Bude suggests that we need to be able to "adopt the perspectives of others [and] respond resiliently and flexibly to changing situations" $(2014 / 2018$, p. 11). It should not be our aim "to resist these processes but to reorganize them and redirect them towards new ends" (Hardt \& Negri, 2000, p. xv).

In the context of this book, the question is whether the phenomena described here resonate in the stories. How present are global flows for the network actors and bloggers? Are they aware of the cultural differences and do they make them the subject of their stories? Do they embrace the opportunities proffered by the Third Space when communicating with people from other cultures?

To the extent that the narratives refer to online communication, all narrators are somehow aware of the worldwide transparency of digital stages, which is one of the conditions for criss-crossing flows of communication and information. But this knowledge remains undetermined. The global public sphere has no clear profile in the narratives. It is a different case with the narrators who crossed geographical borders thanks to educational mobility, who travelled across other continents, who took part in international projects, or who intentionally initiated transnational communication processes with the help of digital technologies. In these cases there is 
an intensive appraisal of expected or perceived cultural differences as well as attempts by the network actors and bloggers to adjust their own behaviour to take account of these differences. Remember the Turkish student who was worried when he came to Austria that he would encounter little warm-heartedness and was now in the process of establishing whether that was really the case or not, or whether there were other differences which he had not anticipated, and how he would manage to make friends in his new surroundings. Whether he recognizes and deals appropriately with cultural differences affects whether he can "arrive" in his new surroundings. The American student was confronted with criss-crossing communication flows as a participant in an international online project (see Sect. 4.6.1). By participating in the project, he became aware of differences in communication, which he used as an opportunity to scrutinize established forms of communication in his own culture. The Arab narrators, in turn, saw the communicative interconnectedness of the world thanks to digital media as a welcome phenomenon rather than a provocation, as discussed in several passages of this book. This surely has something to do with the fact that they view their countries as being on the periphery of world affairs, with their cultural distinctiveness wrongly conveyed by the dominant media or ignored by the global community, but they can present them to a public worldwide thanks to digital media. ${ }^{7}$ Digital online networks like Mideast Youth (n.d.) or CrowdVoice (n.d.) are described by the Arab narrators in the narrations about setting out and breaking away as spaces which come very close to the Third Space. They see their function as both forcing transnational exchange in the region and supporting international communication. This goal opens up the possibility of global and local communication flows criss-crossing. Differences of opinion are expressly desired; such differences are described by the founder of the network Mideast Youth (n.d.) as an information gain. She explained: "If I lose that [the network Mideast Youth], it means I lose a lot of important points of view and perspectives that are not represented in the media."

Cultural flows and hybridization do not appear to have had much impact on the stories included in this study. However, it is a question of developmental trends which will certainly become more intensive in an increasingly entangled world and, thus, will surely become indisputable challenges for upcoming generations.

\footnotetext{
${ }^{7}$ This does not rule out their criticizing certain elements of their cultures, which is, after all, one of the manifestations of the narrations about setting out and breaking away told by the Arab network actors and bloggers.
} 


\subsection{ROUND-UP}

The characteristics of sociocultural upheaval described in this book do not leave the narrations of the network actors and bloggers unaffected. There are plenty of indications that these characteristics do not go unnoticed, even when the participants in the study were not necessarily aware of their being phenomena of upheaval. In those narrations in which criticism of traditional institutions and systems is in the foreground, there is a definite focus on social change in the narrative practices. Regardless of whether change happens or is consciously aimed at, the narrations have similarities on the actional level. They document searches for alternative value orientations, for strategies for organizing a life in the plural, or for managing boundaries, and experiments with self-representation. The Western narrators feel challenged to act as individuals; the Arab narrators, in contrast, describe how their actions are linked more strongly to a collective strategy. Whether their inspirations are individual or collective, it is all about the search for and the establishment of new life forms. Whether it is their intention or not, the search for new life forms lays the foundation of new cultural practices.

As becomes clear from the narrations, digital media make an appearance in the subjects' confrontation with phenomena of sociocultural upheaval in more ways than one. Firstly, they represent and support change, increasing the pluralization of fields of life; accelerating the blurring of borders between the public and the private; facilitating, as transnational media, global flows and the crossover of flows of information and communication. At the same time, they present themselves to network actors and bloggers as instruments and stages for coming to terms with phenomena of upheaval. Faced with the impending fragmentation of experiences, they use the potential of the media to create coherence, making use of the virtual stages for their attempts at individualization or for practising skills which will be useful in the future. Whether we are looking at the role of digital media as representatives of sociocultural upheaval or their role as instruments which help us come to terms with this upheaval, both roles are inextricably linked with the fact that media are culturespecific (Müller-Funk, 2002, p. 177). Every society gives rise to its own media which develop in accordance with certain principles and, therefore, media represent trends in that society. When using them as instruments, subjects adopt the meaning attached to the media by the society they are in. Adoption does not mean mere reproduction of meaning, however; it 
opens new latitudes for individual interpretations. The potential in the media comes up against autonomous subjects who have been moulded by their past and who are endowed with different individual abilities to select, differentiate, and reflect. That explains differences in the practices of grappling with the phenomena of transformation described here as well as varying positions in reaction to this transformation.

\section{REFERENCES}

Babka, A., \& Posselt, G. (2012). Vorwort [Preface]. In A. Babka \& G. Posselt (Eds.), Über kulturelle Hybridität; Tradition und Übersetzung (pp. 7-16). Wien: Turia + Kant.

Barker, C. (2003). Cultural studies: Theory and practice. London: Sage.

Bauman, Z. (1991). Modernity and ambivalence. Cambridge: Polity.

Bauman, Z. (2000). Liquid modernity. Cambridge: Polity.

Beck, U. (1992). Risk society: Towards a new modernity (M. Ritter, Trans.). London: Sage. (Original work published 1986)

Beck, U., \& Sopp, P. (1997). Individualisierung und Integration: Neue Konfliktlinien und newer Integrationsmodus? [Individualization and integration: New lines of conflict and new modes of integration?]. Opladen: Leske + Budrich.

Bhabha, H. K. (1994). The location of culture. London: Routledge.

Bhabha, H. K. (2012). Round-Table-Gespräch [Round table discussion] (S. Seitz, M. Zirngast, \& G. Posselt, Trans.). In A. Babka \& G. Posselt (Eds.), Über kulturelle Hybridität; Tradition und Übersetzung (pp. 59-77). Wien: Turia + Kant.

Bude, H. (2018). Society of fear (J. Spengler, Trans.). Cambridge: Polity. (Original work published 2014)

Carstensen, T., Ballentien, J., \& Winker, G. (2014). Arbeitsalltag im Internet: Umgang mit mehrdimensionalen Entgrenzungen [Everyday work in the internet: Dealing with the multidimensional blurring of borders]. In T. Carstensen, C. Schachtner, H. Schelhowe, \& R. Beer (Eds.), Digitale Subjekte: Praktiken der Subjektivierung im Medienumbruch der Gegenwart (pp. 29-80). Bielefeld: transcript.

Cavarero, A. (2000). Relating narratives: Storytelling and selfhood (P. A. Kottman, Trans.). London: Routledge.

CrowdVoice. (n.d.). Retrieved from https://majal.org/crowdvoice-org

Dirlik, A. (2010). Globale Moderne: Die Moderne im Zeitalter des globalen Kapitalismus weiterdenken [Global modernism: Thinking ahead about modernism in the age of global capitalism]. In M. Boatcă \& W. Spohne (Eds.), Globale, multiple und postkoloniale Moderne (pp. 31-52). München: Rainer Hampp. 
von Eimeren, B., \& Frees, B. (2011). Drei von vier Deutschen im Netz-ein Ende des digitalen Grabens in Sicht? Ergebnisse der ARD/ZDF-Onlinestudie 2011 [Three out of four Germans are online-is this the end of the digital divide? Results of the ARD/ZDF's online study in 2011]. ARD/ZDF-Onlinestudie. Retrieved from http://www.ard-zdf-onlinestudie.de

Foucault, M. (1997). Of other spaces: Utopias and heterotopias (J. Miskowiec, Trans.). In N. Leach (Ed.), Rethinking architecture: A reader in cultural theory (pp. 330-336). New York, NY: Routledge. (Original work published 1967)

Habermas, J. (1990). Strukturwandel der Öffentlichkeit: Untersuchungen zu einer Kategorie der bürgerlichen Gesellschaft; Mit einem Vorwort zur Neuauflage 1990 [The structural transformation of the public sphere: An inquiry into a category of bourgeois society; Reprint with new preface]. Frankfurt am Main: Suhrkamp. (Original work published 1962)

Habermas, J. (1992). The structural transformation of the public sphere: An inquiry into a category of bourgeois society ( $\mathrm{T}$. Burger with the assistance of F. Lawrence, Trans.). Cambridge: Polity. (Original work published 1962)

Hardt, M., \& Negri, A. (2000). Empire. Cambridge, MA: Harvard University Press. Hepp, A. (2015). Transcultural communication (K. Tribe, Trans.). New York, NY: Wiley-Blackwell.

Hess, S., \& Lenz, R. (2001). Kulturelle Globalisierung und Geschlecht: Ein Buchprojekt [Cultural globalization and gender: A book project]. In S. Hess \& R. Lenz (Eds.), Geschlecht und Globalisierung. Ein kulturwissenschaftlicher Streifzug durch transnationale Räume (pp. 10-33). Helmer: Königstein.

Honneth, A. (1995). A fragmented world: On the implicit relevance of Lukács' early work (C. W. Wright, Trans.). In C. W. Wright (Ed.), The fragmented world of the social: Essays in social and political philosophy (pp. 50-60). Albany, NY: State University of New York Press. (Original work published 1990)

Hurrelmann, K., \& Albrecht, E. (2014). Die heimlichen Revolutionäre: Wie die Generation $\Upsilon$ unsere Welt verändert [The secret revolutionaries: How Generation Y is changing our world]. Weinheim: Beltz.

Jurczyk, K., \& Oechsle, M. (Eds.). (2008). Das Private neu denken: Erosionen, Ambivalenzen, Leistungen [Rethinking the private: Erosions, Ambivalences, Accomplishments]. Münster: Westfälisches Dampfboot.

Keupp, H. (2015). Reflexive Sozialpsychologie [Reflexive social psychology]. Unpublished manuscript, Department of Sociology, LMU Munich.

Kraus, W. (2000). Identität als Narration: Die narrative Konstruktion von Identitätsprojekten [Identity as narration: The narrative construction of identity projects]. Retrieved from http://web.fu-berlin.de/postmoderne-psych/berichte3/kraus.htm

Meyrowitz, J. (1985). No sense of place: The impact of electronic media on social behavior. New York, NY: Oxford University Press.

Mideast youth. (n.d.). Retrieved from https://mideastyouth.com/ 
Mitchell, W. J. T. [William]. (2003). Me++: The cyborg self and the networked city. Cambridge, MA: The MIT Press.

Müller-Funk, W. (2002). die kultur und ibre narrative: eine einführung [Culture and its narrative: An introduction]. Wien: Springer.

Müller-Funk, W. (2012). Nachwort: Transgressionen und dritte Räume; Ein Versuch, Homi Bhabha zu lessen [Afterword: Transgressions and Third Spaces; An attempt to read Homi Bhabha]. In A. Babka \& G. Posselt (Eds.), Über kulturelle Hybridität; Tradition und Übersetzung (pp. 79-88). Wien: Turia + Kant.

Nederveen, P. J. (2010). Global multiculture: Cultures, transnational culture, deep culture. In C. Baraldi, A. Borsari, \& A. Carli (Eds.), Hybrids, differences, visions: On the study of culture (pp. 81-96). Aurora, CO: Davies Group.

Roth-Ebner, C. (2015). Der effiziente Mensch: Zur Dynamik von Raum und Zeit in mediatisierten Arbeitswelten [The efficient person: On the dynamics of space and time in mediatized work environments]. Bielefeld: transcript.

Schachtner, C. (2009). Flows, Differenzen, Hybride, Zugehörigkeit [Flows, differences, hybrids, belonging]. Zeitschrift für internationale Bildungsforschung und Entwicklungspädagogik, 32(3), 4-8.

Schachtner, C. (2013). Im Gespinst der Netze. Soziale und kulturelle Entwicklungstrends im Medienumbruch der Gegenwart [The interconnectedness of networks: Social and cultural trends in the current media revolution]. Medien Journal, 37(4), 18-34.

Soup.io. (2017-2019). Retrieved from https://www.soup.io/

Turkle, S. (2011). Alone together: Why we expect more from technology and less from each other. New York, NY: Basic Books.

Urry, J. (2003). Global complexity. Cambridge: Polity.

Welsch, W. (1988). Wege aus der Moderne: Schlïsseltexte der Postmoderne-Diskussion [Ways out of modernism: Key texts in the postmodern discussion]. Weinheim: VCH Acta Humaniora.

Welsch, W. (1991). Subjektsein heute: Überlegungen zur Transformation des Subjekts [Being a subject today: Reflections on the transformation of the subject]. Deutsche Zeitschrift für Philosophie, 4, 347-365.

Welsch, W. (2001). Auf dem Weg zur transkulturellen Gesellschaft [Heading for a transcultural society]. Paragrana, 10(2), 254-284.

Welsch, W. (2012). Was ist eigentlich Transkulturalität? [What is transculturality actually?]. In D. Kimmich \& S. Schahadat (Eds.), Kulturen in Bewegung: Beiträge zur Theorie und Praxis der Transkulturalität (pp. 25-40). Bielefeld: transcript. 
Open Access This chapter is licensed under the terms of the Creative Commons Attribution 4.0 International License (http://creativecommons.org/licenses/ by $/ 4.0 /$ ), which permits use, sharing, adaptation, distribution and reproduction in any medium or format, as long as you give appropriate credit to the original author(s) and the source, provide a link to the Creative Commons licence and indicate if changes were made.

The images or other third party material in this chapter are included in the chapter's Creative Commons licence, unless indicated otherwise in a credit line to the material. If material is not included in the chapter's Creative Commons licence and your intended use is not permitted by statutory regulation or exceeds the permitted use, you will need to obtain permission directly from the copyright holder. 